\title{
Post-Issue Operating Performance Of Nasdaq IPO's
}

Arvin Ghosh, (E-mail: ghosha@ wpunj.edu), William Paterson University of New Jersey

\begin{abstract}
In the '90s bullish stock markets, it was the IPO which created the bubble of 'excessive exuberance', particularly in the technology-heavy NASDAQ market. In our study we have taken a fair sample of NASDAQ IPOs issued during 1990-2000 in order to examine the post-issue operating performance of these IPOs. We have found that during 1990-1995, the mean post-issue one-month return was 1.67\%, the mean six-month return was $4.28 \%$, and the mean one-year return was $5.23 \%$, respectively. This could be compared with the results for the 1996-2000 period when the mean one-month return was $3.29 \%$, mean six-month return was $16.96 \%$, and the mean one-year return was $19.97 \%$, respectively. As for the debt/asset and debt/equity ratios for the same two periods, the former was $11.98 \%$ and $15.23 \%$ for the two periods, and the latter ratio was 5.38\% in 1990-1995 and 3.13\% in 1996-2000. This clearly shows that the NASDAQ bubble was mainly created by the equity issues, not by the issuance of debt securities. Using the multiple regression equations, we also have found that only the first-day closing price was consistently and negatively associated with annual returns. Obviously, the phenomenon of initial underpricing played a big role in determining the annual return of the NASDAQ IPOs during the last decade in the U.S. securities markets.
\end{abstract}

\section{Introduction}

e nitial Public Offering (IPO) was an important part of the stock market bullishness in the 1990s. Although many IPOs were issued in the New York Stock Exchange, it was the NASDAQ market, however, which played a crucial role in this boom and took the lion's share of IPO issuance. In the so-called 'bubble period' of 1998-1999, hardly a week went by when one or two IPOs did not appear in the capital market. It was quite possible that without the IPOs, the stock market boom of the 1990s would not have been sustained for such a long time and with such vigor as to push the U.S. stock prices to a historical height. In the ' 90 s bullish stock markets, it was the IPO which created the bubble of 'excessive exuberance,' particularly in technology-heavy NASDAQ market.

In our study we have taken a fair sample of NASDAQ IPOs issued during the years covering 1990-2000. Our main objective is to examine the post-issue operating performance of these IPOs as undergone during the last bullish period in the United States securities markets. We have excluded from our sample of the Internet IPOs, mainly because we want to take out the speculative bubble created by these IPOs. Instead, we have concentrated on those NASDAQ IPOs which survived when the so-called 'bubble' burst in the late 2000, and which showed strong promise of survival in the years ahead. Only by studying these IPOs can we find some kind of 'permanency' in the turbulent stock market that we witnessed during 1990-2000.

\section{Literature Review And Data Source}

The IPO firms principally came into being after 1970. However, only a few firms then went through initial public offerings, as Jain and Kini (1994) in their sample of 682 IPO firms found only 12 IPOs that were issued before 1980. It was only after 1982 that the IPO market took off, and exploded during the bullish stock market period of 19912000. Here the most important studies of IPO performance were conducted by Jay Ritter and his collaborators. Ritter

Readers with comments or questions are encouraged to contact the author via email. 
(1991), and Loughran and Ritter (1995) documented severe underperformance of initial public offerings (IPOs) during the past twenty years. They had suggested that investors might systematically be too optimistic about the prospects of firms that were issuing equity for the first time.

The opposite evidence was posited by Brav and Gompers (1997) who investigated the long-run underperformance of the IPO firms in a sample of 934 venture-backed IPO firms from 1975-1992. They found that venture-backed IPOs outperformed nonventure-backed IPOs using equal weighted returns. They also found, applying Fama-French (1993) three-factor asset pricing model and other benchmark measures, that venture-backed companies did not significantly underperformed, while the smallest nonventure-backed firms did. Their conclusion is that underperformance is not an IPO phenomenon, that underperformance is a characteristic of small, low book-to-market firms regardless of whether they are IPO firms or not.

Degeorge and Zackhauser (1993) were the first ones who examined the operating performance of the IPO firms. But they had studied a special type of IPO firms, namely, reverse leveraged buyouts (LBOs). Jain and Kini's article (1994) was the most relevant regarding post-issue operating performance of the IPO firms. Here they investigated the change in operating performance of firms as they make the transition from private to public ownership. They found a significant decline in operating performance subsequent to the initial public offering. They also found a significant positive relationship between post-IPO operating performance and equity retention by the original entrepreneurs, but no relation between post-IPO operating performance and the level of initial underpricing. Interestingly, we have found the opposite relationship between the initial underpricing and post-issue operating performance of the IPOs as our regression analysis implied. Jain and Kini also found post-issue declines in the market-to-book ratio, price-earnings ratios, and earnings per share of the IPO firms they covered in their study.

There are three reasons given in Finance literature for IPO underperformance. First is the agency problem relating to a firm's going public from private management where there is a potential for increased agency costs, as explained by Jensen and Meckling (1976) in their seminal article. Second reason is that managers try to window-dress their accounting numbers before going public, so that the pre-IPO performance is overstated and post-IPO performance is understated. And the third explanation is that generally the companies time their issues to periods of unusually good performance levels, which may be difficult to maintain in future.

We will address the same question anew, i.e., the underperformance (or otherwise) of the NASDAQ IPOs. The following are the principal data sources for our IPO analysis of the '90s:

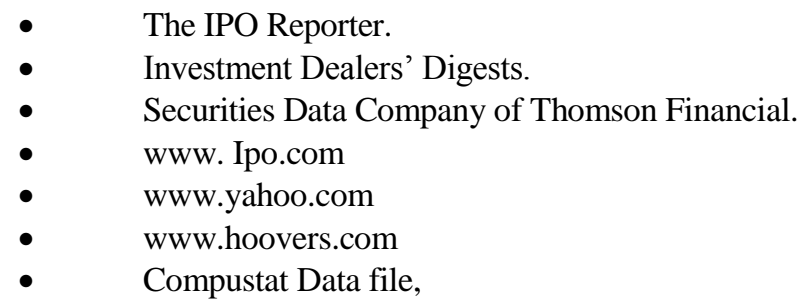

Among these sources, Securities Data Company has become the most prominent one. Then comes the Compustat Data file where we may find the archival data to calculate the long-run performance of the IPOs. The other sources in the Web sites just supplement the missing data not to be found elsewhere. We should remember in this context that the IPO data are still too scattered to be found in one prime source. It will take years to build a comprehensive data-base encompassing the universe of all IPOs. Here Jay Ritter's efforts to fill that void deserves our professional gratitude.

\section{Empirical Findings}

In Table 1, we have shown the first-day return, second-day return and third-day return of our sample of NASDAQ IPOs, issued during 1990-2000. We find that the mean first-day return increased from 3.29\% in 1990 to $76.61 \%$ in 2000 - over 22 times jump in ten years. But the highest increase took place in 1999 during the so-called 'bubble' year. 
However, the second-day mean return during the same period was negative - from $1.26 \%$ in 1990 to $-0.46 \%$ in 2000 . The same trend was evidenced in the mean third-day return - from $1.58 \%$ in 1990 to $-2.45 \%$ in 1999 , and $-0.23 \%$ in 2000 . Obviously, the speculative fervor of the first-day return of the NASDAQ IPOs cooled off in later days when the profit-taking took place and there was considerable sell-off by the institutional investors.

Table 1

Initial Returns of the NASDAQ IPOs, 1990-2000

\begin{tabular}{|c|c|c|c|c|c|c|}
\hline \multirow[t]{2}{*}{ Year } & \multicolumn{2}{|c|}{ First Day Return } & \multicolumn{2}{|c|}{ Second Day Return } & \multicolumn{2}{|c|}{ Third Day Return } \\
\hline & Mean & Median & Mean & Median & Mean & Median \\
\hline 1990 & 3.29 & 3.98 & 1.26 & 2.10 & 1.58 & 1.01 \\
\hline 1991 & 1.34 & 1.59 & $(0.14)$ & 0.80 & $(2.38)$ & 0.80 \\
\hline 1992 & 2.56 & 2.83 & 0.43 & 0.60 & $(1.53)$ & $(0.95)$ \\
\hline 1993 & 3.57 & 3.02 & $(0.60)$ & $(0.45)$ & $(2.73)$ & $(2.60)$ \\
\hline 1994 & 4.68 & 4.33 & 0.18 & 0.26 & 0.62 & 0.93 \\
\hline 1995 & 7.45 & 6.92 & $(1.72)$ & $(3.60)$ & $(1.12)$ & $(3.60)$ \\
\hline 1996 & 21.34 & 16.30 & 1.01 & 1.00 & 1.64 & 2.10 \\
\hline 1997 & 20.33 & 10.00 & 1.11 & 1.70 & 3.27 & 4.50 \\
\hline 1998 & 12.32 & 7.50 & 0.74 & $(1.80)$ & $(7.32)$ & (5.90) \\
\hline 1999 & 84.15 & 48.20 & $(1.57)$ & $(1.10)$ & $(2.45)$ & $(4.70)$ \\
\hline 2000 & 76.61 & 50.70 & $(0.46)$ & $(1.60)$ & $(0.23)$ & $(1.10)$ \\
\hline
\end{tabular}

In Table 2, we have calculated the one-month, six-month, and one-year return of the NASDAQ IPOs covered by our study for the period 1990-2000. While in 1990, the one-month return was $6.10 \%$, and in 1999 it was $6.65 \%$, in 2000, however it was a paltry $0.12 \%$, when the IPO market started to slide downward. Similarly, the six-month return in 1990 was $-10.03 \%$, but increased to $80.32 \%$ in 1998 and $29.97 \%$ in 1999 , while turning into $-64.37 \%$ in 2000 . But the one-year return, while quite high to the tune of $31.83 \%$ in 1990 , jumped to $52.12 \%$ in 1999 , and $44.84 \%$ in 2000 . It seemed that the IPO market was still 'hot' at the end of 2000, and slowed considerably only in 2001, when the 'bubble' collapsed totally and the IPO market was in a downward spiral.

Table 2

One Month, Six Month, and One Year Returns of NASDAQ IPOs, 1990-2000

\begin{tabular}{|c|c|c|c|}
\hline Year & One Month Return & Six Month Return & One Year Return \\
\hline & Mean & Mean & Mean \\
\hline 1990 & 6.01 & $(10.03)$ & 31.83 \\
\hline 1991 & 2.90 & 16.77 & (36.56) \\
\hline 1992 & $(17.86)$ & (26.46) & 80.32 \\
\hline 1993 & 23.46 & 55.20 & 29.97 \\
\hline 1994 & 2.76 & $(53.70)$ & $(64.37)$ \\
\hline 1995 & $(34.45)$ & $(44.50)$ & $(68.20)$ \\
\hline 1996 & 8.02 & 31.83 & $(18.08)$ \\
\hline 1997 & 15.40 & $(36.56)$ & 34.78 \\
\hline 1998 & $(13.70)$ & 80.32 & $(9.35)$ \\
\hline 1999 & 6.65 & 29.97 & 52.12 \\
\hline 2000 & 0.12 & $(64.37)$ & 44.84 \\
\hline
\end{tabular}




\begin{tabular}{|c|c|c|}
\hline \multicolumn{3}{|c|}{$\begin{array}{c}\text { Table } 3 \\
\text { Summary Returns of the NASDAQ IPOs, } \\
1990-1995 \text { and } 1996-2000 \text { Periods }\end{array}$} \\
\hline & Mean & Median \\
\hline \multicolumn{3}{|c|}{$1990--1995$} \\
\hline One Month Return & $1.67 \%$ & $1.83 \%$ \\
\hline Six Month Return & $4.28 \%$ & $4.12 \%$ \\
\hline One Year Return & $5.23 \%$ & $5.56 \%$ \\
\hline \multicolumn{3}{|c|}{$1996-2000$} \\
\hline One Month Return & $3.29 \%$ & $3.14 \%$ \\
\hline Six Month Return & $16.96 \%$ & $15.25 \%$ \\
\hline One Year Return & $19.97 \%$ & $20.38 \%$ \\
\hline
\end{tabular}

In Table 3, we have given the summary measures of one-month, six-month and one-year returns for 1990-1995 and 1996-2000 periods. We find that during 1990-1995, the mean post-issue onemonth return was $1.67 \%$, the mean six-month return was $4.28 \%$, and the mean one-year return was $5.23 \%$, respectively. This could be compared with the results for the 1996-2000 period when the mean one-month return was $3.29 \%$, mean six-month return was $16.96 \%$, and the mean one-year return was $19.97 \%$, respectively. The notion that 1996-2000 was a phenomenal period for the IPO market was borne out by the fact that both the mean six-month and mean oneyear return jumped by $296 \%$ and $282 \%$, respectively, during the later period as compared to the earlier period of the bullish stock markets.

In Table 4, we have shown the selected asset management ratios of the NASDAQ IPO sample firms during 1990-2000. While the mean inventory turnover ratio was 6.59 times in 1990, it jumped to 18.86 times in 2000 . But the mean fixed asset turnover ratio declined considerably during the same period - from 13.60 times to 6.75 times. The decline was also prominent in the working capital turnover when in 1990 it was 2.07, but became negative in both 1998 and 1999, and increased slightly in 2000. This deterioration of both fixed asset turnover and working capital turnover indicates that both sales and total assets of many NASDAQ companies started to shrink long before the stock price of these companies plummeted during 2000-2001.

Table 4

Selected Asset Management Ratios of NASDAQ IPOs, 1990 - 2000

\begin{tabular}{|c|c|c|c|c|c|c|}
\hline & \multicolumn{2}{|c|}{ Inventory Turnover } & \multicolumn{2}{c|}{ Fixed Asset Turnover } & \multicolumn{2}{c|}{ Working Capital Turnover } \\
\hline Year & Mean & Median & Mean & Median & Mean & Median \\
\hline 1990 & 6.59 & 6.39 & 13.60 & 9.55 & 2.07 & 2.04 \\
\hline 1991 & 8.77 & 5.36 & 6.33 & 4.81 & 0.18 & 1.13 \\
\hline 1992 & 7.64 & 5.48 & 5.48 & 5.76 & 2.00 & 1.76 \\
\hline 1993 & 9.29 & 7.54 & 15.02 & 13.89 & 5.48 & 2.10 \\
\hline 1994 & 14.22 & 13.11 & 14.24 & 12.75 & 4.39 & 2.21 \\
\hline 1995 & 16.62 & 15.35 & 14.41 & 13.74 & 4.06 & 1.73 \\
\hline 1996 & 16.73 & 15.98 & 11.58 & 10.06 & 13.36 & 12.17 \\
\hline 1997 & 15.44 & 13.31 & 9.25 & 6.73 & 13.48 & 12.09 \\
\hline 1998 & 14.70 & 13.64 & 6.53 & 4.88 & $(9.69)$ & $(11.91)$ \\
\hline 1999 & 17.16 & 15.95 & 6.01 & 5.86 & $(4.03)$ & $(3.14)$ \\
\hline 2000 & 18.86 & 17.17 & 6.75 & 5.66 & 1.08 & 1.03 \\
\hline
\end{tabular}

In Table 5, we have calculated the operating efficiency of these NASDAQ firms during 1990-2000. We find that the mean net income per employee in 1990 was $2.67 \%$, but became negative in all the later years of 1997 to 2000 . This is also true for net income per dollar of gross plant and equipment. That the vast majority of IPO firms had no net income can also be seen in average earnings per share statistics for these companies which were negative for all the years covered by our study. While the share price of these stocks soared during the last stock market boom, the net earnings were negative for almost all the IPO firms in the United States during 1990-2000. 
Table 5

Net Income Per Employee, Net Income Per Dollar of Gross Plant \& Equipment, and Average EPS

\begin{tabular}{|c|c|c|c|c|c|c|}
\hline Year & \multicolumn{2}{|c|}{ Net Income Per Employee } & \multicolumn{2}{c|}{$\begin{array}{c}\text { Net Income Per Dollar of } \\
\text { Gross Plant \& Equipment }\end{array}$} & \multicolumn{2}{c|}{ Average EPS } \\
\hline & Mean & Median & Mean & Median & Mean & Median \\
\hline & 2.67 & 2.84 & 0.09 & 0.10 & $(0.06)$ & $(0.02)$ \\
\hline 1990 & 8.56 & 2.29 & 0.54 & 0.47 & $(0.07)$ & $(0.03)$ \\
\hline 1991 & 0.91 & 1.37 & 0.17 & 0.14 & $(0.08)$ & $(0.07)$ \\
\hline 1992 & $(17.55)$ & $(11.39)$ & $(0.72)$ & $(0.67)$ & $(0.13)$ & $(0.11)$ \\
\hline 1993 & 12.13 & 5.07 & 0.65 & 0.83 & $(0.09)$ & $(0.08)$ \\
\hline 1995 & 10.59 & 4.45 & 0.70 & 0.44 & $(0.01)$ & $(0.02)$ \\
\hline 1996 & 12.80 & 7.47 & 1.35 & 1.27 & $(0.16)$ & $(0.15)$ \\
\hline 1997 & $(1.93)$ & $(1.13)$ & $(0.38)$ & $(0.18)$ & $(0.18)$ & $(0.17)$ \\
\hline 1998 & $(6.64)$ & $(6.04)$ & $(1.80)$ & $(1.36)$ & $(4.07)$ & $(3.93)$ \\
\hline 1999 & $(1.86)$ & $(1.66)$ & $(0.58)$ & $(0.69)$ & $(4.23)$ & $(4.18)$ \\
\hline 2000 & $(19.03)$ & $(18.99)$ & $(8.21)$ & $(7.98)$ & $(1.23)$ & $(1.19)$ \\
\hline
\end{tabular}

\begin{tabular}{|c|c|c|}
\hline \multicolumn{3}{|c|}{$\begin{array}{c}\text { Table } 6 \\
\text { Leverage Ratios of the NASDAQ IPOs, } \\
1990-2000\end{array}$} \\
\hline Periods & Debt/Asset Ratio & Debt/Equity Ratio \\
\hline $1990-1995$ & $5.38 \%$ & $11.98 \%$ \\
\hline $1996-2000$ & $15.23 \%$ & $3.13 \%$ \\
\hline $1990-2000$ & $13.61 \%$ & $4.26 \%$ \\
\hline
\end{tabular}

In Table 6, we have shown the leverage ratios for 1990-1995 and 1996-2000 periods, along with the entire decade of 1990-2000. While the debt/asset ratio and the debt/equity ratio in percentage term was $5.38 \%$ and $11.98 \%$, respectively, the former ratio showed a modest gain of $15.23 \%$ in 1996-2000, and the later ratio showed a modest decline during the same period. This clearly indicates that the NASDAQ bubble was mainly created by the issuance of equity issues, not by selling debt instruments.

In order to find out the causal relationship between the IPO return as the dependent variable, on the one hand, and various relevant variables as the independent variables, on the other, we have employed the multiple regression model for our data-set. Here the multiple regression equation is of the form:

$$
\mathrm{AR}=\mathrm{a} 0+\mathrm{b} 1 \mathrm{MC}+\mathrm{b} 2 \mathrm{OP}+\mathrm{b} 3 \mathrm{SO}+\mathrm{b} 4 \mathrm{FC}
$$

Where:

$$
\begin{aligned}
& \mathrm{AR}=\text { Annual Return of different years } \\
& \mathrm{MC}=\text { Market capitalization (\$ million) } \\
& \mathrm{OP}=\text { Offer price }(\$) \\
& \mathrm{SO}=\text { Shares offered (million) } \\
& \mathrm{FC}=\text { First-day closing price }(\$)
\end{aligned}
$$

In Table 7, we have shown the regression results. We find that only the first-day closing price was consistently and negatively associated with the annual returns. Offer price was significant in two of the three equations, but the signs were contradictory. Market capitalization was significant in one equation only, and the number of shares was not significant at all in any of these equations. Thus the significance of the FC variable indicates that the gulf between the offer price and the first-day closing price cut the profit of the IPO companies, particularly in the bullish years of the IPO market in the United States economy. 


\section{Conclusions}

Table 7

Multiple Regression Equations of Annual Return as the Dependent Variable

\begin{tabular}{|l|c|c|c|c|c|}
\hline Dependent & \multicolumn{5}{|c|}{ Independent Variables } \\
\hline \multicolumn{1}{|c|}{ (Ars) } & MC & OP & SO & FC & R2 \\
\hline 1990 Annual & 0.0003 & $-0.0461^{*}$ & -0.0042 & $-0.0980^{*}$ & 0.440 \\
Return (AR1) & $(0.0007)$ & $(0.0028)$ & $(0.0127)$ & $(0.0050)$ & \\
\hline 1995 Annual & $0.0264^{*}$ & 0.0039 & 0.0026 & $-0.0322^{*}$ & 0.398 \\
Return (AR2) & $(0.0055)$ & $(0.0041)$ & $(0.1018)$ & $(0.0005)$ & \\
\hline 2000 Annual & -0.0059 & $0.0166^{* *}$ & 0.0095 & $-0.0810^{*}$ & 0.376 \\
Return (AR3) & $(0.0018)$ & $(0.0094)$ & $(0.0069)$ & $(0.0374)$ & \\
\hline
\end{tabular}

Standard errors of the independent variables are in parentheses.

* $5 \%$ level of significance.

** $10 \%$ level of significance.

We have found that, although the mean first-day return jumped from $3.29 \%$ in 1990 to $76.61 \%$ in 2000 , the mean second-day and third-day returns were negative during the same period. During 1990-1995, the mean post-issue one-month return was $1.67 \%$, mean sixmonth return was $4.4 .28 \%$, and mean one-year return was $5.23 \%$, respectively. This could be compared with the results for the 1996-2000 period when the mean one-month return $3.29 \%$, mean six-month return was $16.96 \%$, and mean one-year return was $19.97 \%$, respectively. All this indicates that speculative fervor took place on the first day of the IPO issues as compared to the subsequent days, and that 1996-2000 constituted the exception years for the NASDAQ IPOs as compared to the previous years.

As to the operating efficiency of the NASDAQ IPOs in our sample, mean inventory turnover was much higher in 2000 in comparison of 1990, but both the fixed asset turnover and working capital turnover were lower in 2000 as compared to 1990. The same decline was true for net income per employee and net income per dollar of gross plant and equipment when they were negative in 2000 in comparison of 1990. The average EPS, which was slightly negative in 1990 went down much further in 2000. As to the debt/asset ratio, it increased considerably in 1996-2000 as compared to 1990-1995, but the debt/equity ratio dipped modestly during the same comparative periods. This clearly shows that the NASDAQ 'bubble' was mainly created by the equity issues, not by the issuance of debt securities. Using the multiple regression equations, we also have found that the first-day closing price was consistently and negatively associated with the annual returns. Obviously, the phenomenon of initial underpricing played a big role in determining the annual return of the NASDAQ IPOs during the last decade in the U.S. securities markets.

\section{References}

1. Affleck-Graves, J., S. Hedge, and R. E. Miller, 1996, "Conditional Price Trends in the Aftermarket for Initial Public Offerings," Financial Management, 25-40,

2. Asquith, D., J. D. Jones, and R. Kieschnick, 1998, "Evidence on Price Stabilization and Underpricing in Early IPO Returns," Journal of Finance, 53, 1759-1773.

3. Brav, A. and P.A. Gompers, 1997, "Myth or Reality? The Long-Run Underperformance of Initial Public Offerings: Evidence from Venture and Nonventure Capital-Based Companies," Journal of Finance, 52, 17911821.

4. DEGeorge F. and R. Zackhouseer, 1993, “The Reverse LBO Decision and Firm Performance," Journal of Finance, 48, 1323-1348.

5. Fama, E. and K. French, 1993, "Common Risk Factor in the Returns on Stocks and Bonds," Journal of Financial Economics, 33, 3-56.

6. Ghosh, Arvin, 2002, "Mispricing and Flipping of the Internet IPOs," (Working Paper).

7. Jain, B.A. and O.Kini, "The Post-Issue Operating Performance of IPOs," Journal of Finance, 49, 1699-1726.

8. Jensen, M.C. and W. Mechling, 1976, "Theory of the Firm: Managerial Behavior, Agency Costs and Ownership Structure," Journal of Financial Economics, 3, 306-360.

9. Krigman, L., W. H. Shaw, and K. L. Womack, 1999, "The Persistence of IPO Mispricing and the Predictive Power of Flipping," Journal of Finance, 54, 1015-1044.

10. Loughran, T. and J.R. Ritter, 1995, “The New Issuer Puzzle,” Journal of Finance, 50, 165-199.

11. Ritter, J.R., 1991, “The Long-Run Performance of Initial Public Offerings,” Journal of Finance, 46, 3-27. 